\title{
天然气晚期强充注与塔中奥陶系深部碳酸盐岩储集 性能改善关系研究
}

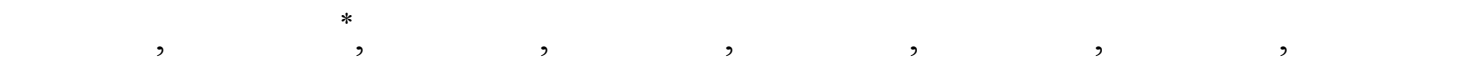 \\ (1) 中国石油勘探开发研究院, 北京 100083; \\ (2) 中国石油塔里木油田勘探开发研究院, 库尔勒 841000 \\ * 联系人, E-mail:zhuguangyou@petrochina.com.cn \\ 2008-10-07 收稿, 2009-05-04 接受 \\ 国家重点基础研究发展计划(编号: 2007CB209500)和国家自然科学基金(批准号: 40602016, 40773032)资助项目
}

摘要＼cjkstart近年来中国海相碳酸盐岩油气勘探发现了一批大型油气田, 尤其在深层获得数个 重大新发现，展示了良好的发现前景. 塔中地区是塔里木盆地的一级构造单元，那里的 奥陶系良里塔格组灰岩礁滩体蕴藏着丰富的天然气资源，储层为陆棚边缘礁滩体，以低 孔-特低孔、低渗为特征, 非均质性强, 目前埋深在 4500 6500 m. 研究发现, 良里塔格组 深部储层的形成和分布除受早期高能沉积相带、溶蚀作用等控制外，喜山期以来发生的 天然气强充注过程形成裂缝网络, 对优化和改善储集层性能具有重要作用. 重点探讨了 天然气晚期强充注与深层奥陶系碳酸盐岩储集性能改善的关系, 建立了相应的机制与模 式, 有利于对勘探革区的预测评价.

关键词

裂缝

优质碳酸盐岩储层

深层储层

奥陶系

塔中 I 号断裂带

塔里木盆地
中国海相沉积盆地主要发育在古生代, 蕴含有 丰富的油气资源. 由于经过多旋回叠合改造, 油气分 布极为复杂 ${ }^{[1 \sim 9]}$, 特别是碳酸盐岩储层, 目前埋藏一 般都较深, 储层致密化严重, 非均质性强烈, 预测难 度较大, 长期以来制约了中国海相碳酸盐岩油气的 勘探步伐 ${ }^{[10,11]}$. 近年来, 随着勘探技术的进步和研发 力度的加强, 一批大型碳酸盐岩油气田被发现, 同时 也揭示出深部优质储集层 ${ }^{[12 ~ 20]}$, 这些发现为中国海 相油气勘探带来了新的希望, 展示出中国海相碳酸 盐岩巨大的勘探潜力, 并促成近两年来中国古生界 海相深部层系成为油气勘探的热点和学者们关注的 焦点.

这些海相碳酸盐岩大型油气田的发现得益于近 年来储层理论研究新进展的指导和支撑: 含油气盆 地成岩作用的时空分布与发育规律的深层次开展、流 体-岩石相互作用机制与分布、成岩系统分级与成岩
作用时空格架、成岩圈闭与成烃演化结合等方面的基 础研究工作 ${ }^{[21 \sim 34]}$, 极大地拓展了油气的勘探范围和 有效储层的预测精度, 有力地支持了近期碳酸盐岩 油气勘探. 特别是塔中地区(主要围绕 | 号断裂带)上 奥陶统碳酸盐岩礁滩复合体大面积富含油气的发现, 体现出储层研究的重要性. 该区奥陶系良里塔格组 灰岩储层非均质性强烈, 有效储层的形成受多种因 素控制, 且复合叠加, 预测难度大. 诸多学者开展了 卓有成效的研究工作 ${ }^{[35-44]}$, 认为有效储层的分布 受高能沉积相带的严格控制; 其次储层受成岩作用 改造强烈, 其中岩溶作用是最重要的建设性成岩作 用(塔中 45 井为典型的埋藏热液岩溶型储层 ${ }^{[45]}$ ); 后 期构造变形作用产生断裂与裂缝, 改善储集性能, 形 成的孔、洞、缝系统, 这三者间的结合可以确定出 有利储层的分布范围, 这些认识有效指导了塔中地 区油气勘探, 这也是塔中地区探井成功率较高的 
重要原因.

构造活动对断裂和裂缝的发育具有举足轻重的 作用, 是其形成的重要动力源. 事实上, 塔中地区在 喜马拉雅运动以来(简称喜山期), 构造相对比较稳定, 没有发现在地震上可以识别的断层, 而且塔中 I 号 断层也早在海西期就停止活动, 因此喜山期发育的 裂缝主动力可能不是构造作用. 研究认为, 喜山期以 前, 塔中 | 号带奥陶系良里塔格组储层储集性能相 对较差, 不具备大规模储油空间, 仅在局部区域存在 油气充注, 大部分早期孔隙没有沥青, 天然气充注成 藏主要发生在喜山期. 喜山期盆地快速沉降, 凹陷区 大量裂解气形成, 塔中 | 号断裂虽然停止活动, 但是 由于 | 号带两侧沉积岩性的差异和构造位置的悬殊, 输导天然气的功能是存在的. 大量高成熟的天然气 沿塔中 | 号带向上运移, 良里塔格组储层虽然对于 储油和运油条件来讲是较差的, 但是对于输气来说 还是可以的, 天然气在向前推进过程中, 迫使原有的 微小缝隙扩大或延长或岩石破裂形成新的微裂隙, 并促使裂缝沿 I 号断裂带向更远的方向发育, 这也 是目前看到的天然气沿塔中 I号带富集的重要原因.

\section{1 塔中地区油气地质背景}

塔中奥陶系是塔里木盆地目前油气勘探的重点 层系. 该区奥陶系碳酸盐岩的勘探始于 1989 年, 在 通过三维地震攻关和地质综合研究的基础上 ${ }^{[12]}$, 于 2005 年发现了塔中। 号坡折带奥陶系碳酸盐岩大型 凝析气田，蕴含了丰富的天然气资源.

塔中在区域构造位置上隶属于中央隆起带中段 的塔中低隆起, 由多个次级构造带组成的大型背斜 构造. 塔中 I 号断裂带为塔中低凸起北部一狭长形 的构造带, 是塔中低凸起与满加尔凹陷的分界, 为近 反“S”型、北西西走向的复杂构造带(图 1), 延展长度 超过 $260 \mathrm{~km}$. 塔中 I 号断裂是控制塔中台背斜及次 一级断裂形成、发展的主断裂, 其他断裂均为 I 号断 裂控制的次级断裂, 在平面上与 I 号断裂有一定的角 度关系, 并向塔中। 号断裂收玫, 呈北东东向展布 (图 1).

塔中 | 号断裂在加里东期形成, 早海西期活动 强烈, 海西中晚期基本停止活动, 在晚海西期停止活 动以后，断裂没有明显的位移，是一个比较稳定的持 续沉降的区域. 塔中 I 号断裂带控制了塔中的构造 格局以及塔中上奥陶统棚缘礁滩复合体的沉积演化.
沿着塔中 | 号带发育的上奥陶统良里塔格组礁滩体, 分布长约 $200 \mathrm{~km}$, 宽 3 10 km, 面积 $1000 \mathrm{~km}^{2}$ 以上 (图 1), 是目前塔里木盆地发现的规模最大的礁滩复 合体有利储集相带发育区，同时也是塔中地区奥陶 系碳酸盐岩油气最富集的区带.

塔中 | 号带奥陶系从上到下可分为上奥陶统桑 塔木组、良里塔格组以及下奥陶统鹰山组和蓬莱坝组 (图 1). 上奥陶统与志留系及下奥陶统均为不整合接 触. 良里塔格组沉积时期, 紧邻塔中 | 号断层西侧, 发育了碳酸盐台地边缘沉积体系. 良里塔格组分为 5 个岩性段：良一 良五段(图 1). 良里塔格组沉积早期 (良四 良五段), 为开阔台地相泥晶灰岩、泥质灰岩和 泥晶藻屑灰岩沉积; 中晚期(良一 良三段)发育厚度 为 $80 \sim 300 \mathrm{~m}$ 的礁滩复合体、丘滩复合体相生物灰岩 和粒屑灰岩，局部发育有滩(礁丘)、滩间海相泥晶灰 岩、粒屑泥晶灰岩, 是重要的储集岩系, 有效储层厚 度在 $30 \sim 80 \mathrm{~m}$.

\section{2 储层成岩演化与油气充注}

\section{1 储层特征}

塔中地区晚奥陶世发育陆棚-斜坡-盆地沉积体 系. 塔中 I 号带礁滩复合体主要发育在 I号断裂带 西侧的台地边缘, 其礁滩体的发育过程严格受控于 沉积环境的变化. 通过对薄片分析、岩芯描述和缝洞 统计认为, 储集空间类型主要有孔、洞、缝三大类. 其 中孔洞主要与溶蚀作用相关, 储集空间类型主要包 括: 粒内溶孔、铸模孔、粒间溶孔、晶间溶孔、生物 体腔孔、生物格架孔、超大型溶孔和溶洞等. 大量岩 芯物性分析数据统计表明, 孔隙度分布范围为 $0.24 \%$ 6.2\%，均值为 $1.45 \%$; 侧向渗透率平均值为 $2.96 \times 10^{-3} \mu^{2}$. 垂直渗透率均值大约是径向渗透率 的 $1 / 7$, 反映了垂直缝或高角度缝对储集层渗透性能 的贡献 ${ }^{[35]}$. 在孔隙度变化不大的情况下, 岩芯中裂缝 条数增多, 渗透性能明显变好, 由此可见, 裂缝可以 有效地改善储层物性.

\section{2 储层成岩演化}

良里塔格组有效储层的形成明显受高能沉积环 境、溶蚀作用和构造破裂作用等的控制. 特别是成岩 早期大气水溶蚀作用和埋藏期溶蚀作用，它是该区 提高储层孔渗性能的重要建设性成岩作用. 大气淡 水溶蚀阶段主要包括同生期大气淡水溶蚀和良里塔 格组晚期大气淡水溶蚀成岩阶段. 礁滩体骨架孔、粒 

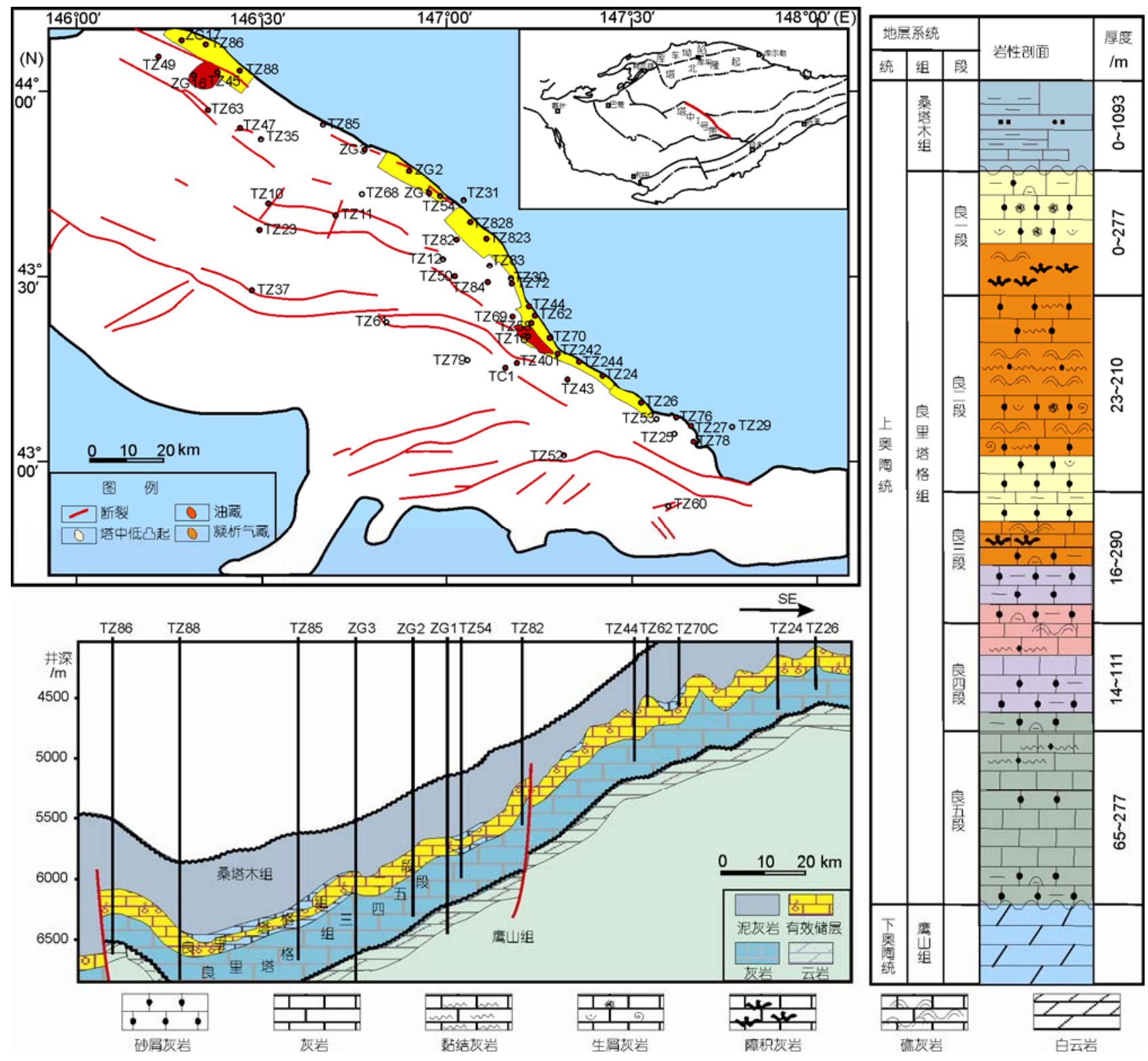

图 1 塔里木盆地塔中地区奥陶系油气分布与岩性组合图

间孔等原生孔隙发育，孔隙度大致在 $25 \%$ 40\%左右 (图 2). 在大气淡水溶蚀作用之前, 发生胶结作用, 纤 状方解石围绕颗粒边缘生长, 形成栉壳状环边胶结 物, 导致原生粒间孔缩小，孔隙度降低到 5\% 15\%。 当海平面相对下降, 粒屑滩暴露在大气淡水成岩环 境下, 发生选择性溶蚀, 形成大量粒间溶孔、粒内溶 孔、铸模孔、超大溶孔和溶洞等溶蚀孔洞, 虽然一部 分溶蚀孔洞被渗流粉砂、泥质或泥晶方解石充填或半 充填, 但残余溶蚀孔洞仍使储层孔隙度增加 10\% $20 \%$ (图 2). 在剥蚀面之下存在不同程度的岩溶带, 发
育不同规模的溶蚀孔洞, 被泥质和泥晶方解石充填 或半充填, 虽然总体上充填程度很高, 但残余孔洞还 有一定分布. 埋藏压实成岩作用和胶结作用对储层 破坏作用比较明显, 在压实作用较强的地方颗粒呈 接触状. 随着上覆压力的不断增加, 压实作用逐渐向 压溶作用转化, 深埋藏环境发育高角度缝合线部分 被不溶有机物和泥质充填, 颗粒灰岩中可见高角度 缝合线和沿高角度缝合线周缘发生溶蚀现象.

可见, 良里塔格组台缘礁滩体的成岩作用比较 复杂, 经历了多期胶结作用、溶蚀作用、造缝作用等, 
是多类型、多期次改造叠加的结果. 总体来看建设性 的成岩作用小于胶结和成岩压实等破坏性成岩作用, 因此储层的储集性能是在逐渐变差的; 但是喜山期 形成的裂缝明显改善了储集层性能.

\section{3 油气充注期次}

塔中地区存在三期重要的油气充注成藏过程, 其中前两期以油为主(图 2); 而塔中 I 号带良里塔格 组台缘礁滩体大部分储集层中未能充分捕获到这两 期油气，局部地区可以见到前两期油气的充注(生物 标志物证实), 可能是油气储集条件不具备或输导条 件不畅通等因素所致. 油气的地球化学性质与生物 标志化合物特征和流体包裹体数据等证实该区大规 模油气充注成藏时间在喜山期以来. 岩芯微观孔隙
结构表明，早期溶蚀孔中储层沥青不是十分发育，而 且绝大部分孔隙也是半充填-充填, 残余孔隙也比较 干净, 特别是早期形成的裂缝已被半自形-它形的细、 粉晶方解石充填, 充填物中晶间溶孔少见. 因此, 可 以确认台缘礁滩体大部分区域没有大量捕获到前两 期的油气. 而目前见到的大量有效网状裂缝则形成 时间较晚, 主要在喜山期, 裂缝溶蚀扩大现象明显, 裂缝的延伸方向比较长, 沿着裂缝分布着许多针状 溶孔和中小型溶洞, 缝内胶结充填物几乎没有, 大部 分充填着轻质油、天然气或地层水. 因此, 喜山期油 气的充注及其发生的有机酸溶蚀作用, 是该区最为 重要的一期埋藏溶蚀作用, 是有效储层形成的关键. 台缘礁滩体中的埋藏溶蚀作用相对比较强烈, 有机

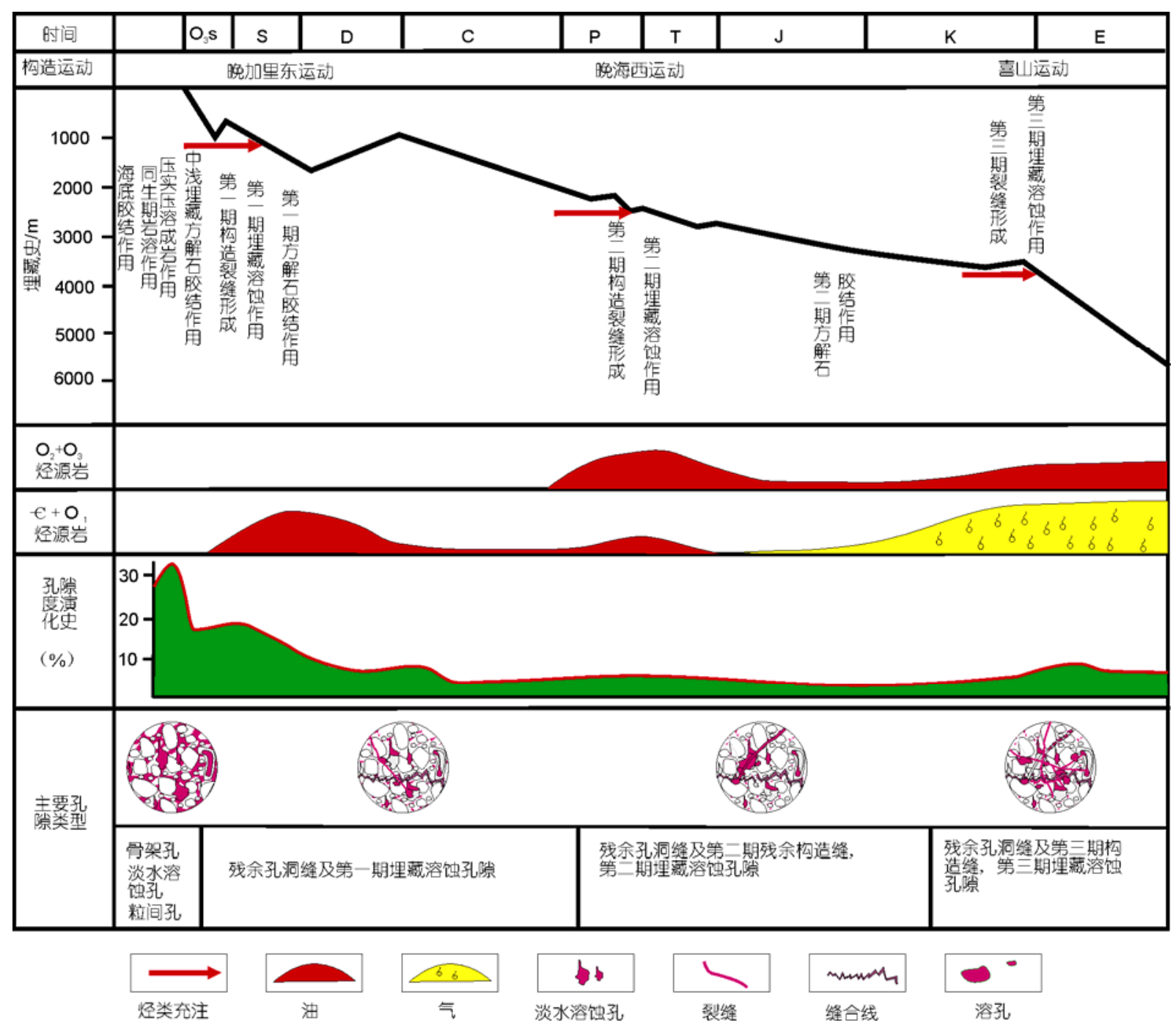

图 2 塔中地区良里塔格组埋藏成岩演化、孔隙演化与油气充注期次示意图 
酸等流体溶蚀作用形成的各种串珠状溶蚀孔洞、扩溶 缝等, 使礁滩相的连通性增加, 扩大了油气储集空间 和油气的流动能力.

\section{3 塔中地区油气分布与天然气地球化学特征}

3.1 油气分布特征

塔中良里塔格组油气的分布与油气地球化学特 征沿着塔中 I 号断裂带自东向西发生着明显的渐变 关系. 从各井天然气产气量来看, 高产气井紧贴 | 号 断裂带分布, 向内带产气量逐渐变小, 其中在 I 号带 北部塔中 86-中古 17 区块、中部塔中 82 区块，日产 气量超过 $50 \times 10^{4} \mathrm{~m}^{3}$ (图 3). 从气油比等值线图来看 (图 4), 气油比值高值区依然是沿着 I号带有规律分 布, 越靠近 I 号带气油比值越高, 高值区气油比值大 于 2000 , 越远离 | 号带, 比值就越低, 说明塔中 I 号 断裂带是一条重要的油气输导通道, 特别是后期以
天然气为主的充注过程, 塔中 I 号断裂带是重要气 源断层.

从塔中 | 号带天然气的地球化学特征来看, 天 然气充注强度较大，后期天然气驱替前期天然气向 前方推进作用十分明显. 从天然气的干燥系数等值 线图上(图 5), 可以明显看出, 沿塔中 | 号带向内带 天然气的干燥系数逐渐变小, 紧贴 I 号带以干气为 主, 说明越靠近 I号带天然气相对充注的时间越晚.

\section{2 天然气地球化学特征与成因}

从天然气的甲烷、乙烷、丙烷等烃类碳同位素等 值线图上(图 6), 也明显体现出自塔中｜号带向西碳 同位素逐渐变轻的特点(由于塔中 45 井区天然气中甲 烷的碳同位素较轻，成因较为复杂，因此文中没有展 示甲烷碳同位素等值线图)，｜号带附近天然气碳同 位素最重、天然气也越干，说明天然气成熟度越高.

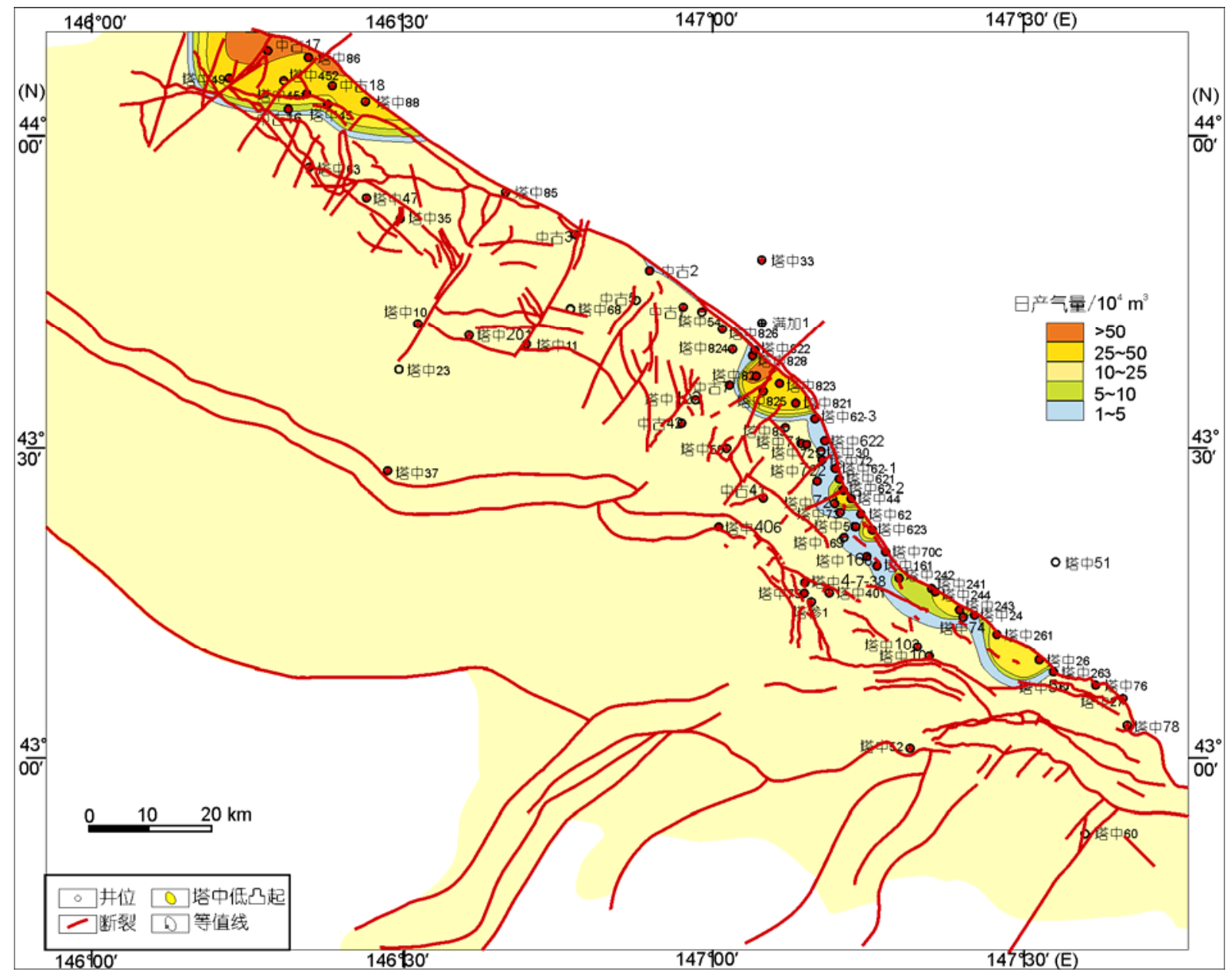

图 3 良里塔格组日产气量等值线图 


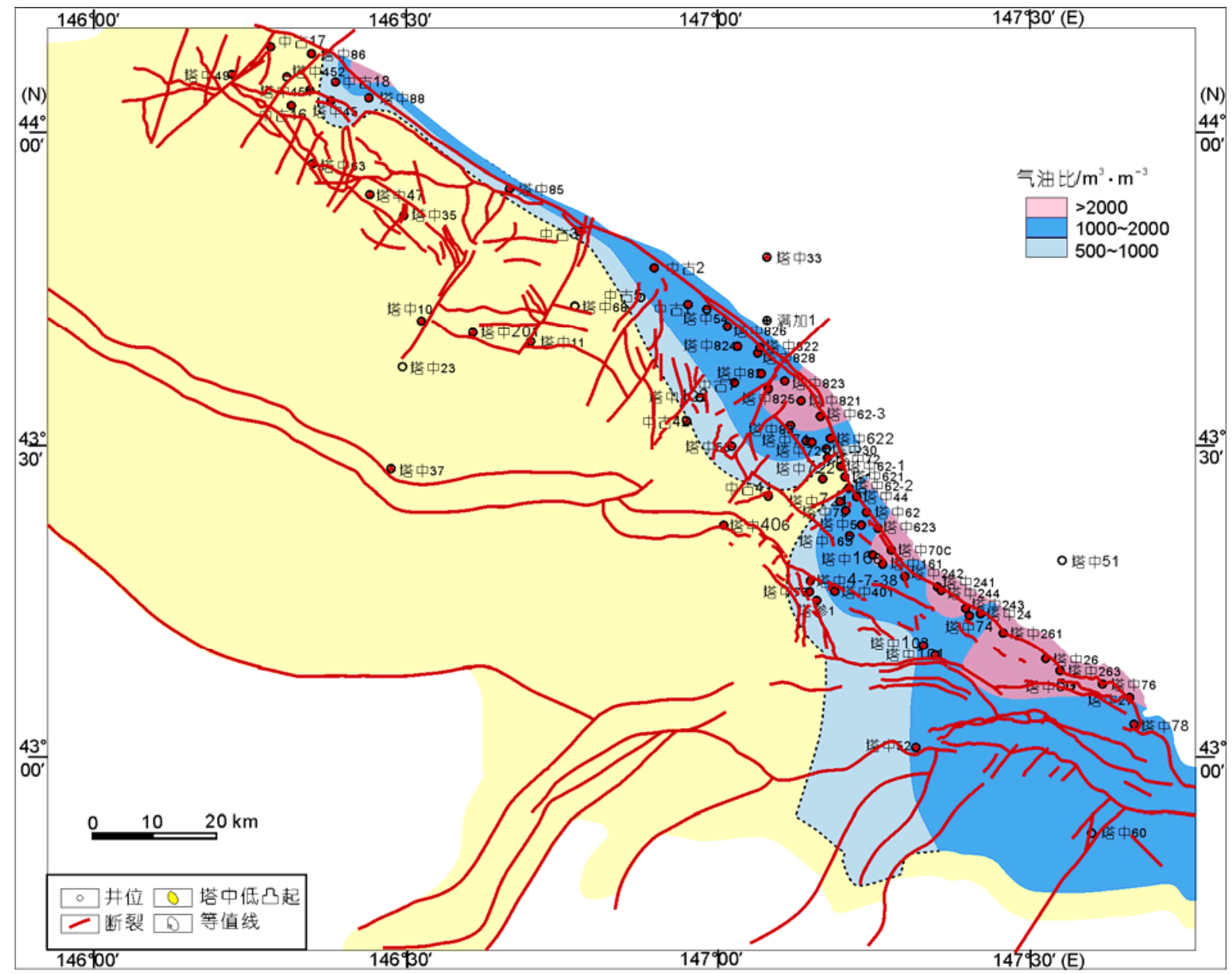

图 4 良里塔格组气油比等值线图

由此可见, 塔中 | 号带喜山期以来天然气充注强度 大, 向前推进作用十分明显, 反映出塔中 I 号断裂带 是重要的天然气输导通道. 但是, 天然气沿 1 号带向 前充注及运移的距离则十分有限, 是储层因素还是 输导体的因素导致了天然气如此有规律的分布、以及 分布范围如此有限呢?

天然气成因研究表明, 塔中 | 号带天然气属于 原油裂解气. 天然气碳同位素分布比较稳定, 甲烷碳 同位素主要分布在-39\% - 37\%o(除塔中 45 井区), 乙 烷碳同位素分布在-37\% - 32\% , 丙烷碳同位素主要 分布在 $-34 \%$ - 30\%, 碳同位素表明该天然气是来自 于母质类型较好的烃源岩. 甲烷-丁烷的碳同位素呈 现出正常序列分布, 没有倒转(图 7), 天然气属于有 机成因.

塔里木盆地烃源岩的分布与演化表明, 该天然 气可能来自寒武系-中下奥陶统烃源岩, 因为这套烃
源岩类型好, 分布范围大, 而且这套烃源岩的热演化 进入大量生气阶段 ${ }^{[46-49]}$. 塔中奥陶系储层温度一般 都低于 $140^{\circ} \mathrm{C}$, 达不到原地油藏裂解的温度条件, 因 此天然气应来自异地的原油裂解气, 通过运移而来 并聚集成藏. 包裹体资料与埋藏史分析认为, 塔中 I 号带良里塔格组台缘礁滩体天然气充注时间在喜 山期.

\section{4 天然气充注与有效裂缝的形成机制}

\section{1 天然气充注强度}

寒武系-中下奥陶统烃源岩规模大, 该套烃源岩 在燕山晚期-喜山期已进入大量生气阶段, 资源评价 认为, 台盆区天然气资源量在 5 万亿立方米以上. 而 且从目前台盆区(主要是塔北和塔中地区)天然气探 明规模、单井日产气量等方面都可以肯定, 天然气具 有较大的充注强度和充注动力. 比如在塔北轮南地 


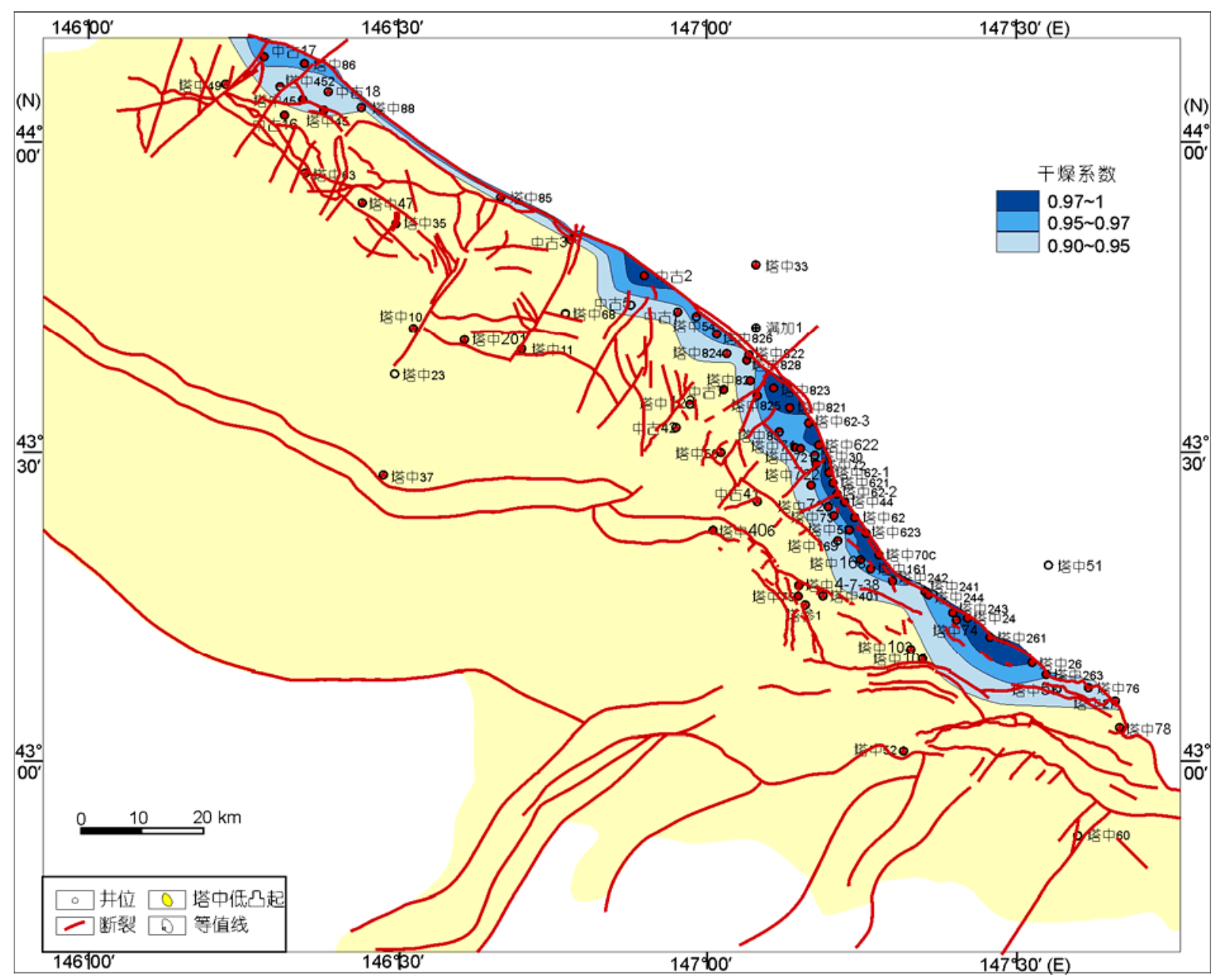

图 5 良里塔格组天然气干燥系数等值线图

区，喜山期天然气的输导通道主要是依靠碳酸盐岩 风化壳不整合面或顺层岩溶带运移, 输导体畅通, 横 向运移距离超过 $60 \mathrm{~km}$, 垂向上天然气可以通过断层 运至中生界、新生界, 可见喜山期天然气的充注强度 之大. 而具有相似充注条件的塔中地区，喜山期天然 气沿 I号带向前充注运移的距离仅在数公里甚至 5 $\mathrm{km}$ 以内, 差别如此之大很可能与输导条件有关.

4.2 塔中地区裂缝的发育特征与有效裂缝的形成时间 塔中｜号带良里塔格组台缘礁滩体储层是孔、 洞、缝结合的储层, 没有裂缝的沟通, 储层基本都没 有油气充注, 这说明裂缝对于改善礁滩体储层的重 要性. 虽然塔中地区奥陶系良里塔格组的裂缝具有 多期成因、多期改造、多期充填的特点 ${ }^{[35,36,39,40]}$, 根 据岩芯及微观观察的裂缝类型、切割关系、充填成分 以及与成岩作用的先后关系来看, 主要有以下几期:
（1）加里东期发育高角度裂缝，缝细小，壁平直 规则, 普见后期裂缝切割穿插现象, 已被半自形-它 形的细-粉晶方解石充填, 无储集能力, 是无效裂缝 (图 8).

（2）形成于晚海西期-印支期以直立的张性缝为 主，缝壁不规则，充填物为中粗晶方解石、萤石等, 大部分已被充填, 少部分可见到扩溶现象.

(3) 主要形成于喜山期的裂缝不仅裂缝分布密 度大, 且未被矿物充填, 但是裂缝规模比较小, 延伸 长度短, 缝较窄, 缝面一般平直, 呈斜交状、树枝状、 水平状和网状, 溶蚀扩大现象明显, 针状溶孔和中小 型溶孔分布于裂缝周围或沿缝的延伸方向分布, 缝 内表现为轻质油、天然气和地层水充填.

根据构造研究的结果 ${ }^{[39]}$, 塔中隆起在其构造演 化中的断裂变形有: 第 I 期为加里东晚期-早海西期, 形成了塔中 I 号断裂带及其伴生断裂系统; 第 II 期 


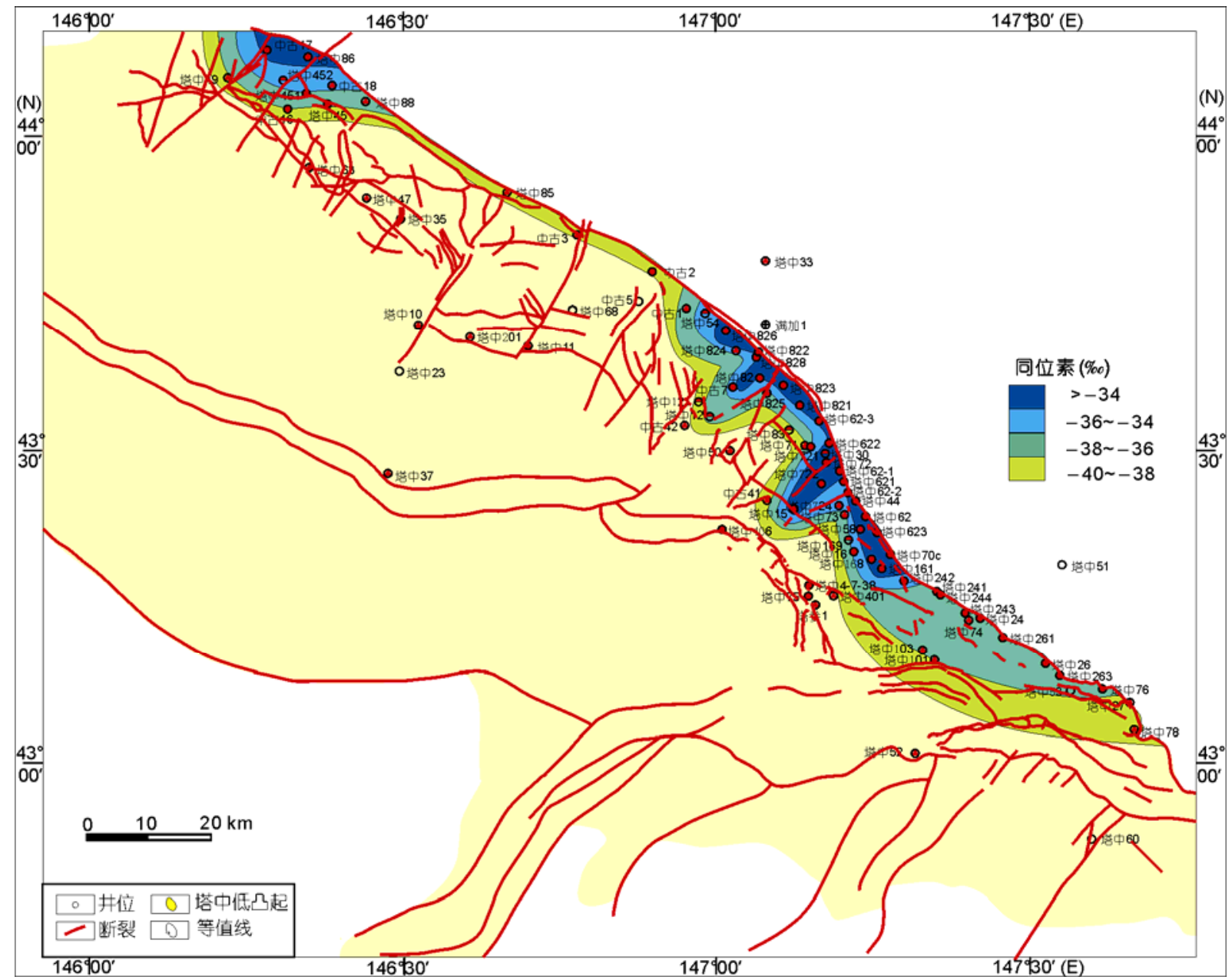

图 6 良里塔格组天然气乙烷同位素等值线图

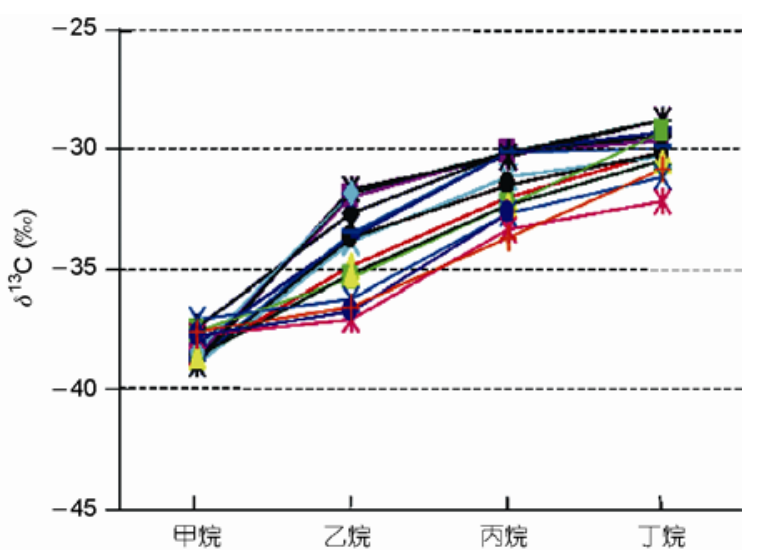

图 7 塔中地区奥陶系天然气碳同位素分布特征

为晚海西期, 形成了塔中 4 断裂和塔中 11 断裂等断 裂系统. 新生代的构造活动主要在塔北和库车地区, 几乎没有波及到塔中地区，那么喜山期形成的新的 裂缝系统很可能就不是构造活动造成的.

\section{3 塔中地区裂缝的微观结构}

虽然在岩芯观察中已发现塔中｜号带良里塔格 组台缘礁滩体储层缝洞十分发育, 缝洞结合, 连为一 体, 是重要的储集空间, 而事实上, 大多数微裂隙是 肉眼无法观察到的. 紫外光下观察发现, 第 III期(喜 山期)裂缝十分发育，不仅裂缝干净未被充填外，裂 缝分枝现象十分明显, 呈现出枝广状的微裂缝和晶 间缝(图 9). 这些枝广状裂缝都很干净, 没有充填物. 在苂光镜下可见缝隙与晶隙及界面缝构成网络状, 与粒间渗流粉砂溶孔和方解石针孔连通(图 9). 大量 薄片观察发现，越靠近！号断裂的井，裂缝越发育， 裂缝密度大; 而远离 । 号断裂带, 裂缝就不发育.

\section{4 裂缝的形成机制}

从塔中１号带良里塔格组台缘礁滩体有效裂缝 平面分布特征来看, 越靠近 I号带有效裂缝越发育, 

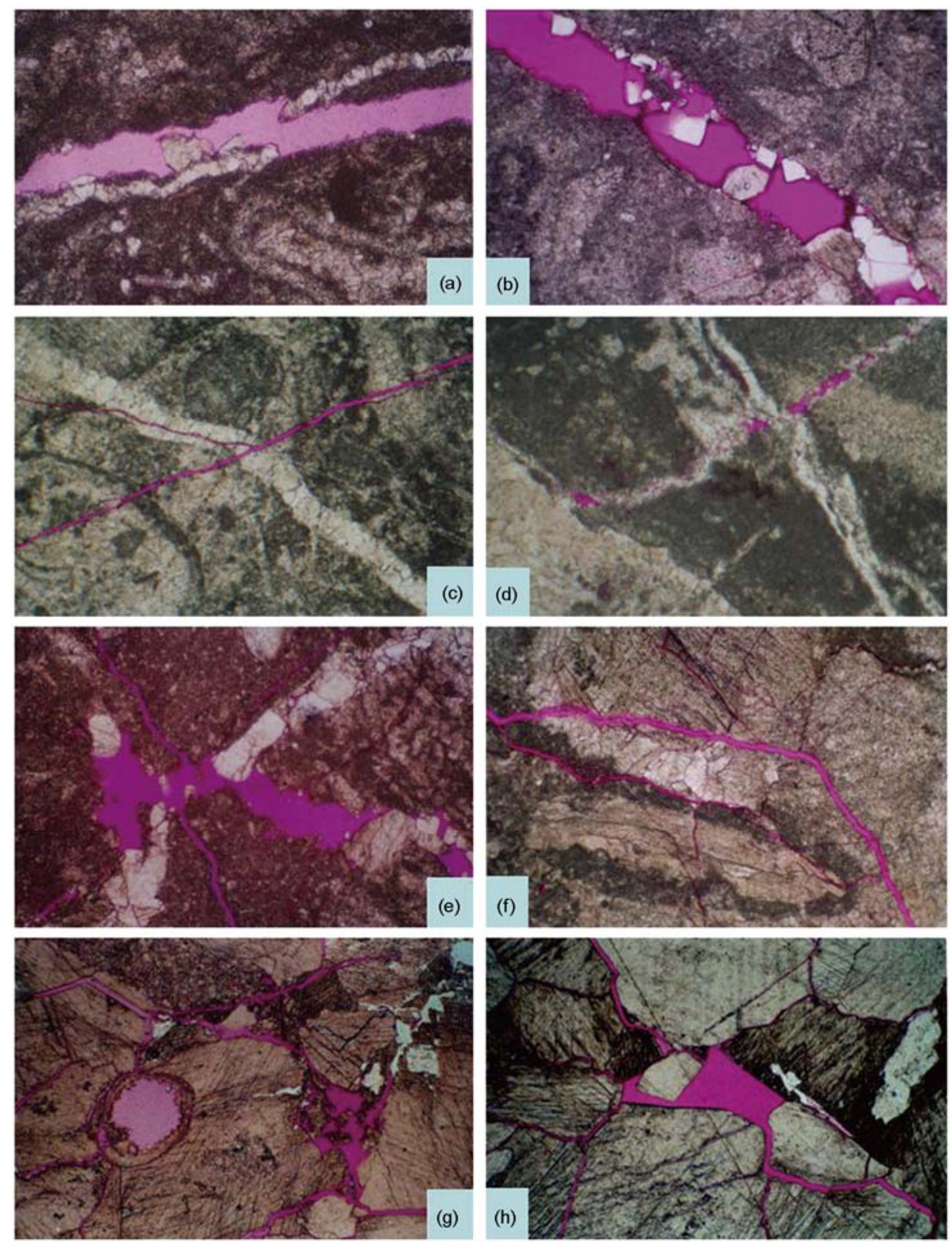

图 8 塔中地区奥陶系良里塔格组多期裂缝微观特征

(a) 塔中 44 井, 晶生屑灰岩, 两期缝, 早期缝被方解石充填, $4888.43 \mathrm{~m}$, 良二段, $\times 80$; (b) 塔中 242 井, 泥晶生屑灰岩, 方解石半充填构造缝, $4501.15 \mathrm{~m}$, 良二段, $\times 50$; (c) 塔中 263 井, 亮晶生屑灰岩, 两期构造缝, 第二期方解石全充填, 第三期未充填, $4317.66 \mathrm{~m}$, 良二段, $\times 50 ;(\mathrm{d})$ 塔中 263 井, 秥结颗粒灰岩, 两期构造缝, 第二期发育串珠状溶孔, $4304.03 \mathrm{~m}$, 良二段, $\times 50$; (e) 塔中 82 井, 泥晶颗粒灰岩, 沿第三期缝分布 的溶蚀孔, $5694.94 \mathrm{~m}$, 良一段, $\times 50$; (f) 塔中 242 井, 泥晶生屑灰岩, 第三期构造缝, $4505.82 \mathrm{~m}$, 良二段, $\times 50 ;(\mathrm{g})$ 塔中 826 井, 亮晶棘屑灰岩, 第三期缝连接溶蚀孔隙, $5664.50 \mathrm{~m}$, 良一段, $\times 50 ;$; (h) 塔中 825 井, 泥晶灰岩, 晶模孔和晶间缝, $5302.16 \mathrm{~m}$, 良二段, $\times 50$, 以上均为红色铸体

也就是说离气源越近, 裂缝密度越大. 根据微电阻率 成像测井分析可知, 裂缝的走向大都与塔中 I 号断裂 带高角度相交, 呈北东-南西向(而已被方解石充填的 早期缝的走向多与塔中 I 号断裂带近于平行), 包括 直立剪切缝、直立复合缝、直立张性缝、水平缝等, 这
些缝的形成很可能是由强烈天然气充注作用导致灰 岩内部组织结构产生与受力方向相适应的微破裂系 统, 而且裂缝发育程度与受力作用的大小有关. 越靠 近 I 号带, 天然气充注动力越强, 裂缝系统也就越发 育，裂缝性储层的厚度也越大(图 10). 另外，岩石缝 

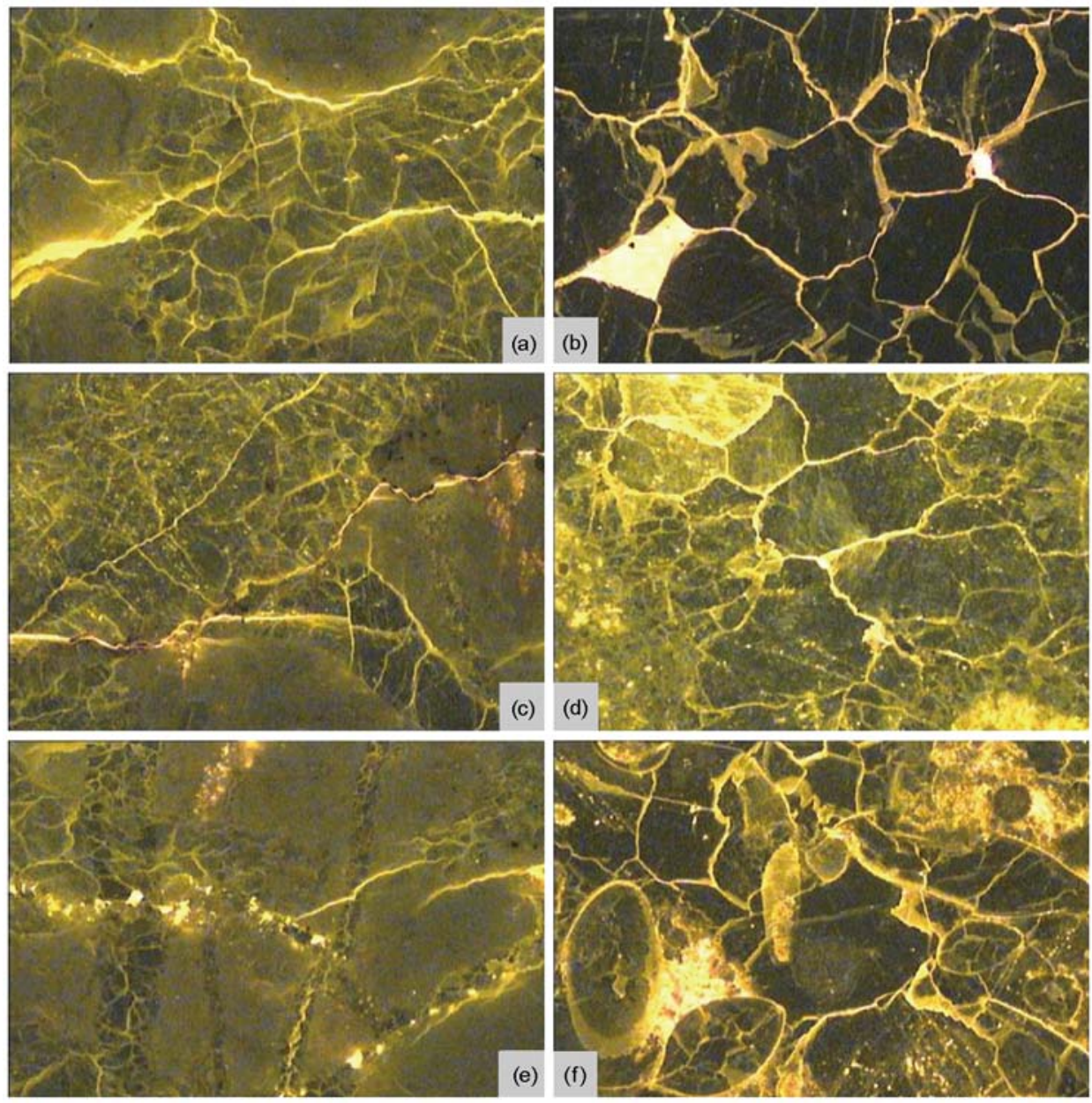

图 9 塔中良里塔格组储层微裂缝和晶间缝紫外光照片

黄色代表含气裂缝和孔隙. (a) 塔中 241 井, 微缝晶隙网络, $4659.78 \mathrm{~m}$, 良二段, $\times 50$; (b) 塔中 241 井, 方解石晶间孔和晶间缝, $4666.63 \mathrm{~m}$, 良二段, $\times 50$; (c) 塔中 241 井, 微缝晶隙网络, $4659.78 \mathrm{~m}$, 良二段, $\times 50$; (d) 塔中 241 井, 晶隙网络, $4642.43 \mathrm{~m}$, 良二段, $\times 50$; (e) 塔中 241 井, 方解石充填半充填缝中的微裂隙, $4659.78 \mathrm{~m}$, 良二段, $\times 50$; (f) 塔中 62 井, 缝隙与晶隙及界面缝构成网络状, 与粒间渗流粉砂溶孔 和方解石针孔连通, $4736.74 \mathrm{~m}$, 良二段, $\times 50$

中早期充填的有机质在后期裂解成气对裂缝的形成 也具有重要的贡献, 造成裂缝发育的非均质性增大.

由于天然气的分子直径远小于油的分子直径, 因此天然气对输导通道的要求就比油小得多，一些 裂隙油不能通过, 而天然气可能就很容易通过. 由于 塔中｜号带良里塔格组台缘礁滩体储层属于低孔低 渗储层, 储油能力较差, 但对于天然气来说可以作为 较好的储层. 天然气在依靠源储压差动力向前推进 的过程中会使原来的微小裂缝张开变宽, 向前延伸 更远，同时还会围绕较大的裂缝产生更多微小的裂 隙网络, 这些裂缝网络是天然气的良好渗流通道. 随 着天然气向前充注动力的减小, 诱发破裂的应力势
必也在减弱, 裂缝发育的密度也逐渐减小, 裂缝的宽 度也逐渐变窄, 最后连天然气也难以通过. 这也是现 今塔中 I 号带良里塔格组台缘礁滩体天然气沿着 | 号带呈带状分布的主要原因.

\section{5 裂缝对储层的改善}

天然气强烈充注导致灰岩产生裂缝的作用过程 对碳酸盐岩储集性能的改善具有十分重要的影响. 这些裂缝网络不仅沟通了孔隙, 更重要是提高储集 层渗滤能力(图 11), 同时也利于油气水等流体的活动 及溶蚀孔洞的继续发育, 形成碳酸盐岩孔-洞-缝系统. 由于塔中奥陶系天然气富含硫化氢，且与四川盆地 川东北地区硫化氢成因类似，均属于 TSR(硫酸盐热 


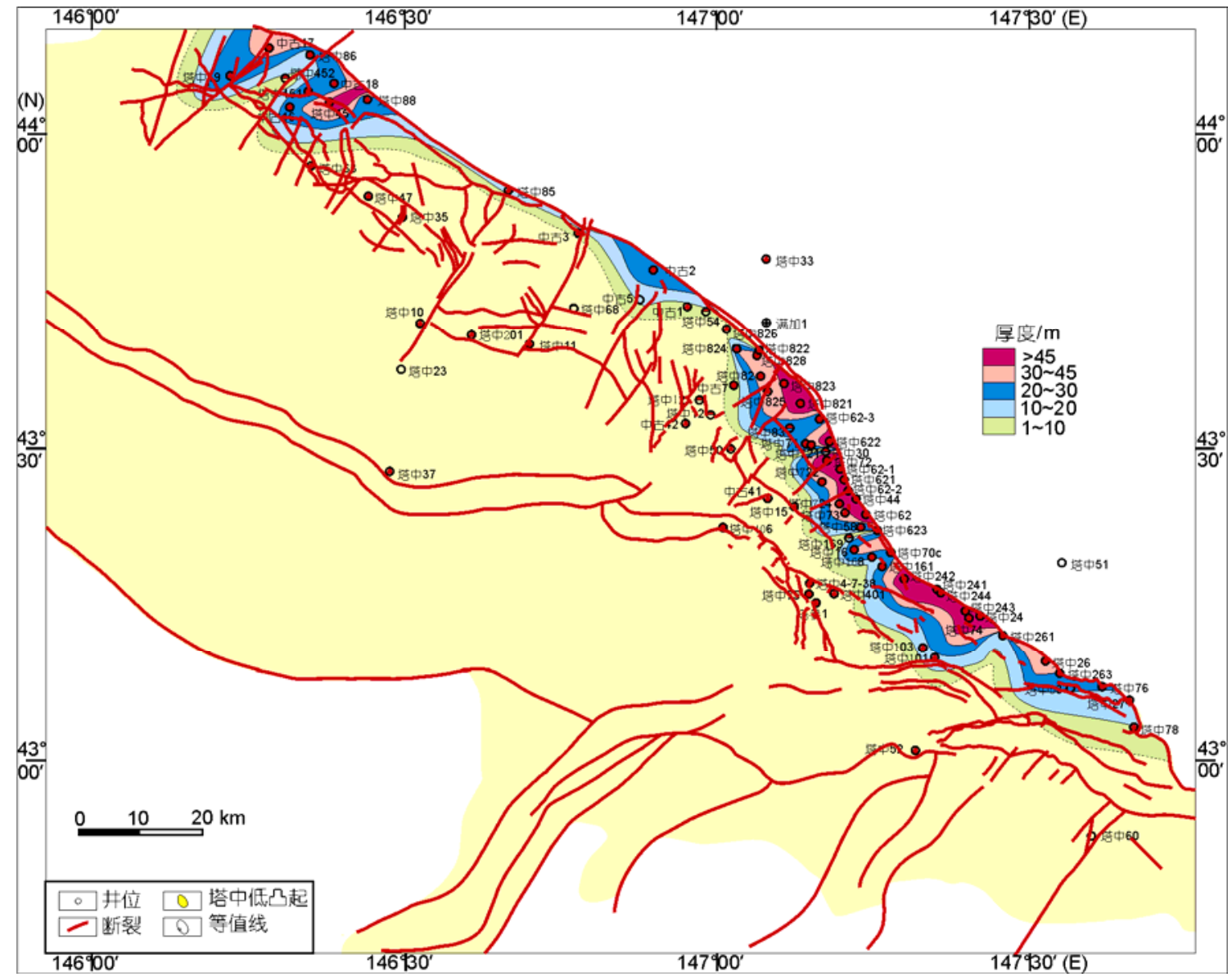

图 10 塔中 | 号带良里塔格组有效裂缝型储层厚度等值线图
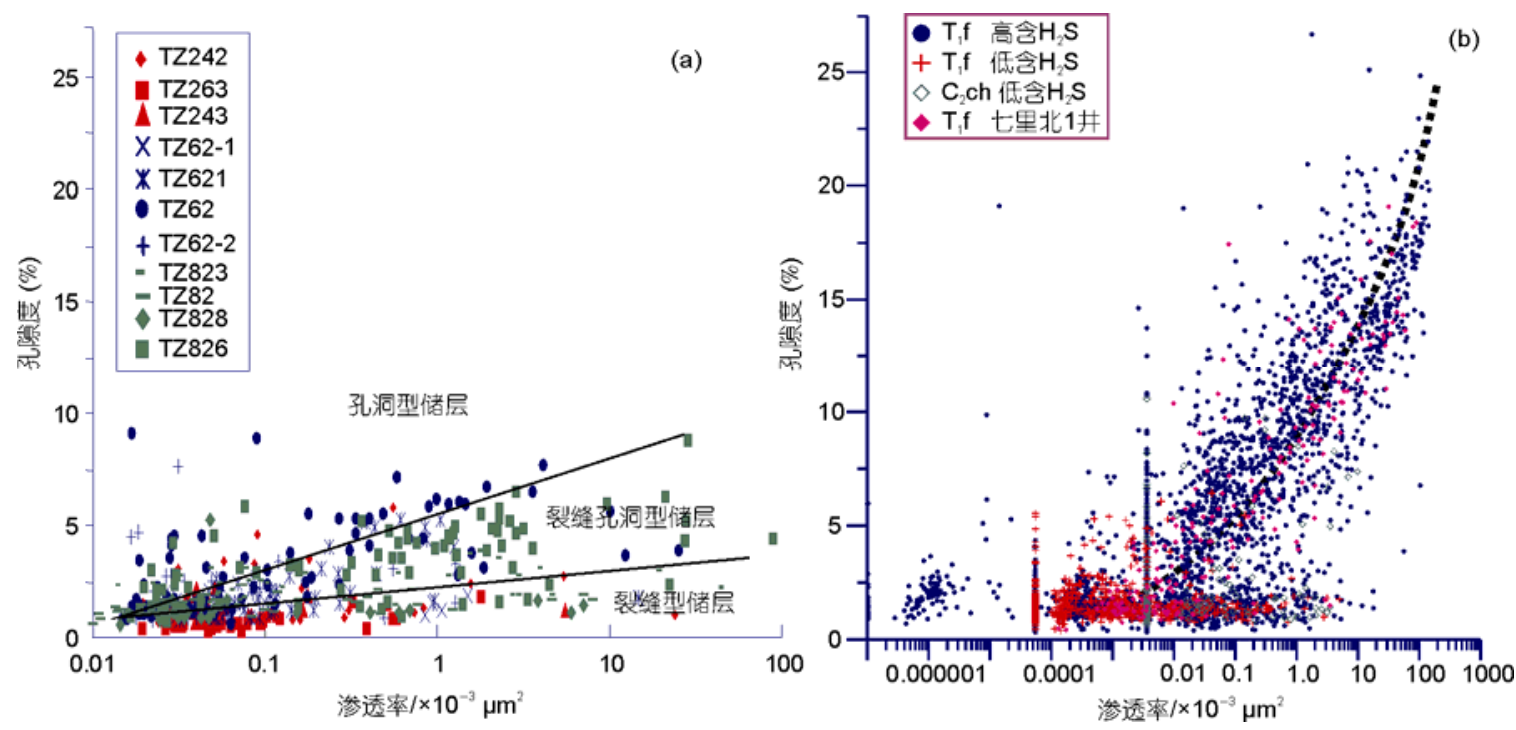

图 11 储层孔渗关系图

(a) 塔中良里塔格组裂缝-孔隙型储层, (b) 川东飞仙关组孔隙型储层. 塔中良里塔格组储层孔隙度与渗透率之间不存在明显的指数关系, 与四川盆地飞仙关组高含硫化氢孔隙型储层相比 ${ }^{[20]}$, 飞仙关组渗透率值在 $1 \times 10^{-3}$ 和 $10 \times 10^{-3} \mu \mathrm{m}^{2}$ 时, 对应的孔隙度值分别是 $7.5 \%$ 和 $12.5 \%$; 而塔中孔隙度值对应的则是 $4 \%$ 和 $5 \%$ 左右, 同等孔隙度条件下, 塔中储层的渗透率明显比四川盆地飞仙关组好, 说明裂缝在改善储层渗 透性能方面具有重要意义 
化学还原作用)成因 ${ }^{[50 \sim 52]}$, TSR 及其形成的硫化氢溶 于地层水后对碳酸盐岩储层具有重要的溶蚀改造作 用 ${ }^{[20]}$, 并能形成新的溶蚀孔隙. 因此由裂缝网络沟通 的孔-洞-缝系统在酸性流体的水-岩相互作用下，溶 蚀作用也更强烈. 比如在塔中 82 井区，显微镜下裂 缝周围粒间溶孔、粒内溶孔、晶间溶孔比较发育, 这 些溶蚀孔隙的形成时间较晚, 与裂缝常形成串珠状 溶孔和溶缝等.

虽然孔洞与沉积相带和暴露溶蚀有关, 但后期 断裂对储集层的改造作用更为重要. 大量取芯分析 数据统计表明, 塔中 I 号带良里塔格组台缘礁滩体 裂缝发育的岩芯的孔隙度比裂缝不发育的岩芯孔隙 度平均值要高出 $0.4 \%$, 而平均渗透率值要高出一倍, 因此裂缝的形成大幅度提高了塔中 | 号带良里塔格 组台缘礁滩体储集层的渗透能力和储集性能，是该 区有效储层形成的关键过程. 这也是目前发现的塔 中Ｉ号带良里塔格组台缘礁滩体储层越靠近 I 号带, 储层的孔渗性也越好的根本原因.

总之, 喜山期以来塔中地区发生的天然气强烈 充注作用导致良里塔格组灰岩储层形成的裂缝网络 系统对天然气大规模运聚具有重要的输导作用, 更 为重要的是, 这些裂缝网络与许多孤立状的孔洞系
统结合形成的孔-洞-缝相结合的一体化系统, 大大改 善了储集性能，优化了储层，扩大了储集能力，是塔 中 | 号带良里塔格组台缘礁滩体大场面凝析气藏形 成的重要因素.

\section{6 结论}

塔里木盆地塔中 | 号带奥陶系良里塔格组礁滩 复合体优质碳酸盐岩储层的形成与分布明显受高能 沉积相带、溶蚀作用和破裂成缝作用的控制.

塔中 | 号带奥陶系良里塔格组天然气来自于寒 武系-中下奥陶统烃源岩形成的原油裂解气，天然气 沿塔中 | 号断裂向内运移, 充注时间在喜山期, 充注 强度大. 在天然气充注的强大动力作用下, 迫使良里 塔格组灰岩原有的微小缝隙扩大或延长或形成新的 微裂隙, 即在天然气充注过程中使小裂缝变成大裂 缝, 短裂缝变成长裂缝, 并扩张形成新裂缝, 形成裂 缝密度更大的裂缝网络系统，优化了储集性能. 这些 裂缝网络与孤立状的孔洞系统结合形成的孔-洞-缝 相结合的孔洞缝一体化系统, 并促进水-岩相互作用 的发生和溶蚀作用的继续进行，大大改善了储集性 能, 是塔中 | 号带良里塔格组台缘礁滩体大场面天 然气藏形成的重要条件.

参考文献

李晋超, 马永生, 张大江, 等. 中国海相油气勘探若千重大科学问题. 石油勘探与开发, 1998, 25: 1-2

赵文智, 汪泽成, 张水昌, 等。中国叠合盆地深层海相油气成藏条件与富集区带。科学通报, 2007, 52(增刊 I ): 9-18

戴金星，秦胜飞，陶士振，等。中国天然气工业发展趋势及其地学理论重要进展。天然气地球科学, 2005, 16: 127一142

张水昌，梁狄刚，张宝民，等. 塔里木盆地海相油气的生成. 北京: 石油工业出版社, 2004

金之钧. 中国海相碳酸盐岩层系油气勘探特殊性问题. 地学前缘, 2005, 12: 15-22

赵文智，王红军，王兆云，等。天然气地质基础研究中的几项新进展及其勘探意义. 自然科学进展, 2006, 4: 393一399

邹才能, 陶士振。海相碳酸盐岩大中型岩性地层油气田形成的主要控制因素. 科学通报, 2007, 52(增刊 I): 32-39

朱光有，赵文智，梁英波，等.中国海相沉积盆地富气机理与天然气的成因探讨. 科学通报, 2007, 52(增刊 I): 46一 57

张水昌，梁狄刚，朱光有，等. 中国海相油气形成的地质基础. 科学通报, 2007, 52(增刊 I ): 19-31

10 赵雪凤, 朱光有, 刘钦甫, 等。深部海相碳酸盐岩储层孔隙发育主控因素研究. 天然气地球科学, 2007, 8: 514一 521

11 朱光有，张水昌，梁英波，等。四川盆地深部海相优质储集层的形成机理及其分布预测. 石油勘探与开发，2006，33: $161-166$

12 周新源，王招明，杨海军，等。塔中奥陶系大型凝析气田的勘探和发现. 海相油气地质, 2006, 11: 45一 51

13 康玉柱。塔里木盆地寒武一奥陶系古岩溶特征与油气分布. 新疆石油地质, 2005, 26: 472-480

14 王招明. 塔里木盆地油气勘探与实践. 北京: 石油工业出版, 2004

15 何君, 韩剑发, 潘文庆. 轮南古隆起奥陶系潜山油气成藏机理. 石油学报, 2007, 28: 44-48[DOI]

16 张水昌，朱光有，梁英波。四川盆地普光大型气田 $\mathrm{H}_{2} \mathrm{~S}$ 及优质储层形成机理探讨. 地质论评, 2006, 52: 230-235

17 马永生. 四川盆地普光超大型气田的形成机制. 石油学报, 2007, 28: 9-14 [DOI] 
18 张水昌, 朱光有. 四川盆地海相天然气富集成藏特征与勘探潜力. 石油学报, 2006, 27: 1-8

19 黄思静, Hairuo Q, 裴昌蓉, 等. 川东三叠系飞仙关组白云岩锶含量\&锶同位素组成与白云岩化流体. 岩石学报, 2006, 22: $2123-2132$

20 朱光有, 张水昌, 梁英波, 等. TSR \& $\mathrm{H}_{2} \mathrm{~S}$ 对深部碳酸盐岩储层的溶蚀改造作用一四川盆地深部碳酸盐岩优质储层形成的 重要方式. 岩石学报, 2006, 22: 2182-2194

21 李忠, 陈景山, 关平. 含油气盆地成岩作用的科学问题及研究前沿. 岩石学报, 2006, 22: 2113-2122

22 黄思静, 石和, 毛晓冬, 等. 早古生代海相碳酸盐的成岩蚀变性及其对海水信息的保存性. 成都理工大学学报(自然科学版), 2003, 30: 9-18

23 黄思静, Hairuo Q, 胡作维, 等. 四川盆地东北部三叠系飞仙关组硫酸盐还原作用对碳酸盐成岩作用的影响. 沉积学报, 2007, 25: $815-824$

24 李忠, 韩登林, 寿建峰. 沉积盆地成岩作用系统及其时空属性. 岩石学报, 2006, 22: 2151-2164[DOI]

25 马永生, 郭形楼, 朱光有, 等. 硫化氢对碳酸盐储层溶蚀改造作用的模拟实验证据一以川东飞仙关组为例. 科学通报, 2007 , 52(增刊 I ): 136一-141

26 顾家裕, 贾进华, 方辉. 塔里木盆地储层特征与高孔隙度、高渗透率储层成因. 科学通报, 2002, 47(增刊): 9-15

27 朱如凯, 郭宏莉, 高志勇, 等. 中国海相储层分布特征与形成主控因素. 科学通报, 2007, 52(增刊 I ): 40-45

28 Williams L B, Hervig R L, Wieser M E. The influence of organic matter on the boron isotope geochemistry of the Gulf Coast Sedimentary basin, USA. Chem Geol, 2001, 174: 445-461[DOI]

29 Wierzbicki R, Dravis J J, Al-Aasm I, et al. Burial dolomitization and dissolution of Upper Jurassic Abenaki platform carbonates, Deep Panuke reservoir, Nova Scotia, Canada. AAPG Bull, 2006, 90: 1843-1861미]

30 Chellie S T, Mazzullo S J, Bischoff W D. Dolomitization of Holocene shallow-marine deposits mediated by sulfate reduction and methanogenesis in normal-salinity seawater, northern Belize. J Sediment Res, 2000, 70: 649—663

31 Moore C H. Carbonate reservoirs: Porosity evolution and diagenesis in a sequence stratigraphic framework. Develop Sedimentol, 2001, 55: $1-423 \underline{[\mathrm{DOI}]}$

32 Davies G R, Smith J L B. Structurally controlled hydrothermal dolomite reservoir facies: An overview. AAPG Bull, 2006, 90: $1641-1690 \underline{[\mathrm{DOI}]}$

33 Heydari E. Meteoric versus burial control on porosity evolution of the Smackover Formation. AAPG Bull, 2003, 87: $1779-1797 \underline{[\mathrm{DO}]}$

34 Zhao W Z, Zhang S C, Li M W, et al. Advances in natural gas geochemistry of Chinese sedimentary basins. Org Geochem, 2005, 36: $1581-1582$

35 杨海军, 刘胜, 李宇平, 等. 塔中地区中一上奥陶统碳酸盐岩储集层特征分析. 海相油气地质, 2000, 5: 73-83 $\underline{\text { [DOI] }}$

36 邬光辉, 李启明, 张宝收, 等. 塔中 I 断裂坡折带构造特征及勘探领域. 石油学报, 2005, 26: 27-30

37 罗春树, 杨海军, 蔡振忠, 等. 塔中 82 井区优质储集层的主探因素. 新疆石油地质, 2007, 28: 589-591

38 孙玉善, 韩杰, 张丽娟, 等. 塔里木盆地塔中地区上奥陶统礁滩体基质次生孔隙成因一以塔中 62 井区为例. 石油勘探与开 发, 2007, 34: 541-547

39 秦启荣, 刘胜, 张宗命. 塔中 I 号断裂带 $\mathrm{O}_{2+3}$ 石灰岩裂缝期次研究. 天然气工业, 2002, 22: 127一128

40 王振宇，严威，张云峰，等。塔中上奥陶统台缘礁滩体储层成岩作用及孔隙演化。新疆地质, 2007, 25: 287-290

41 赵宗举，王招明，吴兴宁，等。塔里木盆地塔中地区奥陶系储层成因类型及分布预测. 石油实验地质, 2007, 29: 40一-47

42 魏国齐, 贾承造, 宋惠珍, 等. 塔里木盆地塔中地区奥陶系构造一沉积模式与碳酸盐岩裂缝储层预测. 沉积学报, 2000, 18: 408-412

43 沈安江, 王招明, 杨海军, 等. 塔里木盆地塔中地区奥陶系碳酸盐岩储层成因类型、特征及油气勘探潜力. 海相油气地质, 2006, 11: 1-12

44 韩剑发, 梅廉夫, 杨海军, 等. 塔里木盆地塔中地区奥陶系碳酸盐岩礁滩复合体油气来源与运聚成藏研究. 天然气地球科学, 2007, 18: 426-435

45 张兴阳，顾家裕，罗平，等. 塔里木盆地奥陶系萤石成因及其油气地质意义. 岩石学报, 2006, 22: 2220-2228

46 贾望鲁, 彭平安. 凝析油充注对油藏沥青质分子结构的影响. 石油勘探与开发, 2003, 30: 112-116

47 张宝民, 赵孟军, 肖中尧, 等. 塔里木盆地优质气源岩特征. 新疆石油地质, 2000, 21: 33- 37

48 张水昌, 张宝民, 王飞宇, 等. 中上奥陶统: 塔里木盆地主要油源层. 海相油气地质, 2000, 5: 16一 22

49 张水昌, 王飞宇, 张保民, 等. 塔里木盆地中上奥陶统油源层地球化学研究. 石油学报, 2000, 21: 23-28

50 朱光有, 张水昌, 梁英波, 等. 川东北地区飞仙关组高含 $\mathrm{H}_{2} \mathrm{~S}$ 天然气 TSR 成因的同位素证据. 中国科学 D辑: 地球科学, 2005, 35: $1037-1046$

51 朱光有, 张水昌, 梁英波. 中国海相碳酸盐岩气藏 $\mathrm{H}_{2} \mathrm{~S}$ 形成的控制因素和预测方法. 科学通报, 2007, 52(增刊 I): 115一125

52 姜乃煌, 朱光有, 张水昌, 等. 塔里木盆地塔中 83 井检测出 2-硫代金刚烷及其地质意义. 科学通报, 2007, 52: 2871一2875 